\title{
Exploring English Speaking Problems In Higher Education: Pre-Service English Teachers' Perspectives
}

Sri Wahyuningsih ${ }^{1}$, Maisyanah ${ }^{2}$

1,2 English Education Department, Institut Agama Islam Negeri Kudus, Kudus, Indonesia

\begin{tabular}{|l|l|l|l|}
\hline Contact: & Sri Wahyuningsih & wahyuningsih@iainkudus.ac.id \\
\hline
\end{tabular}

\section{ABSTRACT}

The purpose of this present study was to explore a dozen Englishspeaking problems encountered by pre-service English teachers in one of Indonesian Higher Educations. The data of this qualitative study were garnered through semi-structured interviews with ten pre-service English teachers at Institut Agama Islam Negeri Kudus and relevant documentation. The results revealed that speaking English fluently is not really easy for pre-service English teachers. In addition, they encountered some problems, including lack of appropriate vocabulary, grammar mastery, correct pronunciation, and lack of confidence. This study presents an implication in accordance with the curriculum development of speaking course in higher education, particularly at Institut Agama Islam Negeri Kudus, including the need to reformulate the speaking course curriculum, emphasizing the integration of technology to arouse the spirits among pre-service English teachers in speaking English. Moreover, the need of providing more chance to speak English for them both inside and outside the class.

\section{KEYWORDS:}

Higher Education;

Pre-Service English

Teachers;

Speaking Problems;

Speaking Anxiety

\section{Introduction}

In spoken language, speaking has a major role in delivering messages or ideas which has different features from the written language. It is a productive skill which is considerably more complex than just conveying words. Additionally, they should foster their students to produce grammatical utterances, logical and meaningful sentences. Spoken interaction is necessary for language learning to occur, but its simple occurrence is insufficient by, and of, itself. In an interactive linguistic environment, such as with the EFL classroom, the right amount and the right kind of verbal interaction must occur simultaneously for learning to take place(Talley \& Hui-ling, 2014). Besides, speakers are encouraged to 
comprehend ideas for the listeners (Thomson, 2017). It is obvious that speaking English is not really easy, especially for non-native speakers.

Another aspect felt by the speakers in speaking English is anxiety which deals with a state of tension in an individual caused by uncomfortable stimulus externally (Basith et al., 2019). Regarding speaking ability, language anxiety especially speaking may be taken into account. Language anxiety is sorts of anxiety particularly associated with foreign language learning areas (Tsai, 2018). In this sense, English language classroom activities are a source of speaking anxiety. Thus, it has correlated with students' unwillingness to speak English. This occurs when they have not mastered a foreign language fully. Horwitz \& Code (1986) cited in (Tsai, 2018) mention three kinds of components of foreign language anxiety, including communication apprehension (feeling the fear with people), test anxiety (fear of exam), and fear of negative evaluation (the fear of how other people listen). Besides, there are some factors to measure oral or speaking proficiency including accuracy, complexity, and fluency (Spring, et al, 2019, p. 90). With regard to this, fluency has become the main component of speaking or oral proficiency. In order to enhance fluency, vocabulary and production of phonological skills are badly essential (Scarpino, 2019, p. 174).

These elaborations denote that besides the aspect of fluency, structure, and vocabulary, anxiety of speaking has become a common barrier in speaking English, especially for non-native speakers. Having a look at the teaching conditions of the Indonesian teachers, the challenges regarding teaching English in Indonesia especially in higher education will give implications for the development of language education, particularly in Indonesia. Understanding the need of acquiring English as an international language and the demands of teaching English, viewed from the perspectives of the Indonesian teachers, will focus on the issues in English 
teaching, including speaking, where native English speakers are preferable over the non-native English speaking teachers (Ulla, 2018).

Likewise, pre-service English teachers at Institut Agama Islam Negeri Kudus are those studying English at English Education Department. They are prepared to be an English teacher and are demanded to acquire English skills, including speaking. However, considering English is not their first language, it is merely believed that they may have some problems in speaking English. Therefore, this article mainly explores some problems of speaking English encountered by pre-service English teachers and promotes possible solutions to overcome these problems and give a better implication in English language teaching in Indonesia.

\section{Method}

This study anchors in qualitative research. The analysis is designed as a descriptive study. It is simply a factual narrative of what happened, spatial and chronological. Therefore, it is immediately or potentially observable, and it can be inferred that there is no manipulation of treatments. Regarding it, this study aims to explore some English-speaking problems viewed from pre-service English teachers' perspectives. In addition, a number of possible solutions are presented to overcome these problems. The result of the study, therefore, would be in the form of descriptive analysis or interpretations. Related to data sources, the data for this study were garnered from semi-structured interviews with ten pre-service English teachers consisting of five female and five male pre-service English teachers at Institut Agama Islam Negeri Kudus. Besides, relevant documentation were used to obtain more relevant data.

\section{Result}

Semi-structured interviews were conducted with ten pre-service English teachers at IAIN Kudus. Further, each interviewee was told to elaborate on their English speaking problems while taking the speaking course. The 
results of interviews were then tape-recorded and transcribed. Based on the interview and documentation, most of them have encountered a dozen problems in speaking English, including the lack of grammar mastery, lack of acquiring English vocabulary, lack of correct pronunciation, and lack of confidence.

\section{Discussion}

As explained in the previous results, the problems of speaking English viewed from the perspectives of pre-service English teachers cover:

\section{Lack of Grammar Mastery.}

Grammar mastery has played a meaningful role in fostering students' speaking skills. In fact, some pre-service English teachers found problems exploring the correct grammar. In this matter, the less mastery of grammar can be taken into account as one of the general problems that hinder their English speaking proficiency. It has been proven by the following data:

"Grammar is one of the crucial aspects needed in speaking fluency. I need to know tenses and its use. In fact, it needs time to speak English by considering the correct tenses" (Student 1, 2021)

Likewise, the problem of grammar mastery is also denoted by another student:

"Acquiring correct grammar has become one of my challenges in speaking English. As the pre-service English teacher, I should be able to speak English well” (Student 2, 2021).

In conjunction with the above descriptions, most pre-service English teachers have reported that to acquire the correct grammar, they should be able to understand certain patterns of grammar before uttering English words. In this sense, this situation highlights that knowledge of grammar has a role as a means of the monitor. As Chomsky reported (Troike, 2006), the innate language such as grammar knowledge is the aspect of the human mind expressed in the brain. Indeed, these pre-service teachers do 
not have more time to explore what they really want to express in speaking matter. Additionally, they need to consider improvisation fast when they want to express utterances. This condition clearly states that they will have grammatical errors when they rely on "feel" for correctness without further planning.

Considering this problem, grammar knowledge is automatically available to learners, especially children, for their L1 and is sometimes usually mastered with no conscious efforts. However, besides grammar knowledge, other knowledge becoming the main element in acquiring language includes morphology and discourse. Morphology deals with parts of words with meaning (morphemes), inflections that convey grammatical information such as tenses and prefixes, and suffixes that may change the meaning of words or their grammatical category. Discourse deals with strategies to connect sentences and organize information across the sentence boundaries, structures for telling stories, engaging in conversations, scripts for interacting, and others.

\section{Lack of Acquiring English Vocabulary}

Mastering vocabulary needs to be taken into account as a pivotal aspect in speaking English. It is in line with the statement of Wood et al., (2018), highlighting that vocabulary has the main role in someone's speaking proficiency. However, some pre-service English teachers at IAIN Kudus have problems in acquiring English vocabulary. In addition, they need more practice in order to make use of English vocabulary well. The lack of acquiring English vocabulary has been advocated by the following preservice English teachers:

"I admit that I have barriers in uttering the correct vocabularies when speaking English. I do not master well idioms, phrases and so on. Therefore, this hinders me to speak English fluently (Student 3, 2021)".

Along with this, another student highlights that: 
"I found difficulties uttering correct vocabularies. I have a lack of vocabulary is caused by the lack of reading some references like book, literatures, and others. In addition, in fact, I seldom watch English movies (Student 4, 2021)".

The description above is also supported by another pre-service English teacher reporting that he has problems choosing the appropriate vocabulary. In addition, he should think for a while before speaking English. It has been proved by the following data:

"I really need time to think for a while when exploring English vocabularies. Indeed, I seldom speak English outside the classroom. It needs more time to enrich my English vocabularies (Student 5, 2021)".

Along with the elaborations above, it could be deduced that most preservice English teachers in the department of English language education agree that the problem of vocabularies has become one of the main aspects they somehow cannot deliver their ideas correctly in English. Moreover, they might think that the problem of vocabulary can hinder the fluency of their English-speaking proficiency. In other words, viewed from the perspective of the pre-service English teacher, the lack of delivering correct English vocabulary may become the general problem in speaking class. However, those who are capable in expressing better vocabularies tend to have better speaking proficiency. Consequently, they tend to be more passive in speaking English.

\section{Lack of Correct Pronunciation}

One of the pivotal aspects of having meaningful roles in speaking fluency is pronunciation which is learned in phonology. Furthermore, it belongs to academic competence that needs to be required for speaking in most educational settings. In interpersonal competence, proficiency in phonology and intelligible productions are crucial for producing successful spoken interaction. Based on the interview, a number of pre-service English 
teachers report that they are supposed to speak accurately to focus on pronouncing English words (particularly less common words) and sound well. In this matter, most of them find problems pronouncing certain vowels and consonants. It has been denoted by the following excerpts:

"I found problems in pronunciation of English words. As we have already known, English words have different sounds. I sometime pronounce inaccuracies English sounds. For example: I have problems in pronouncing vowels and consonants such as I am not too clear of saying sound of 'ae' and 'a" (Student 6, 2021).

Besides, they also report the errors of articulation especially dropped final consonants clusters. However, those errors may not lead to unintelligibility. Surprisingly, most students reveal that they feel confused about words having British and American pronunciations. It has been highlighted by one of the pre-service English teachers:

"I am a little bit misunderstood in the use of both American and British pronunciation. Sometime, I use British and American styles in speaking English (Student 7, 2021)".

Some pre-service English teachers admit that they have not been able to develop the intonation as the native speaker. Along with it, the intonation can be merely considered as one crucial element of their English fluency. It has been described by the following data:

"I have problems in expressing English sentences in good intonation.

Furthermore, I have problems using correct stress in pronouncing English words. Therefore, my production of English sentences cannot run well. Thus, it will be a strange thing for others (Student 8,2021 )”.

From this elaboration, it shows that intonation and pronunciation have played a main role in producing correct utterances. Indeed, some of these pre-service English teachers do not have more chances to the Englishspeaking environment at the previous stages of their learning. 


\section{Lack of Confidence}

Confidence is really needed in enhancing one's speaking skills. Pre-service English teachers in English language education department at Institut Agama Islam Negeri Kudus have less networking outside. Additionally, they may have no more opportunity to get knowledge from numerous perspectives. Consequently, they may feel less confident when they speak English with others, particularly for the new community. In this matter, some pre-service English teachers have less opportunity to have public speaking. The less of the confidence among these pre-service English teachers are elaborated through the following data:

"I have less opportunity to say something in English. This may make me unconfident in speaking English with others. The role of English student's association has not run well. It probably need some interesting activities to pursue students' motivation in learning English (Student 9, 2021)"

"I have no confidence when speaking English in front of other people. I realize that I need more practice speaking English by listening native speakers, watching movie, and others (Student 10, 2021)".

Based on the description above, it could be assumed that students are badly needed to have more opportunity in performing public speaking. The learning activities given by the lecturers are not yet enough to make students speak up in the class. Additionally, some active learning activities outside the class by maximizing the role of English organizations, especially STEC (Stain English Club) and EDSA (English Department Student Association), are merely recommended.

Along with it, being confident when speaking English is very crucial. However, some pre-service English teachers have lack of confidence when they are speaking. They tend to be passive in speaking class. It may be caused by the lack of inputs of English and fantastic activities in English organization. In addition, the programs seem monotonous and less 
improvisations. Therefore, it is recommended to have fantastic and innovative English programs such as having connected with native speakers so that they will be accustomed to listening English words and their confidence in performing something will increase well.

In addition, the lack of innovative programs regarding English organization outside the class has led the students to have less chance in speaking English and making them less confident in speaking English. Surprisingly, students are rarely engaged in English activities and programs outside, such as workshops, seminars, public speaking, and others. As a result, the lack of exposure of English among students may not develop their confidence in speaking English. It is considerably paramount to facilitate them with interesting learning activities and English programs outside the class to build their confidence when interacting with others using English and integrate the activities of speaking using social media like video, YouTube, and so on (Wahyuningsih, 2018; Wahyuningsih \& Dewi, 2019). Moreover, they are highly supported to join a dozen programs in line with their English skills such as seminar, students' exchange, short course and others so that they will be knowledgeable about culture, information, and others. Finally, they hopefully have more confidence and reduce the anxiety of speaking English (Hamzaoğlu \& Koçoğlu, 2016; Pontillas, 2020).

Considering the above English-speaking problems, it seems that Language Development in the Curriculum is badly needed as one of the solutions to overcome these problems considering that the English language education department is a new study program at IAIN Kudus. The obstacles of English courses generally focus on literature, language theories, grammar, and phonology, second language acquisition focusing on increasing the awareness and knowledge in accordance with the language system instead of using the theories and knowledge. Therefore, language development tends to fail in its implementation. In addition, the knowledge and pedagogical materials of the English curriculum possibly 
fail to adopt the students' obstacles expectation to increase their communicative purposes, which can be used in real interaction.

The English curriculum consists of some Islamic, national, and language materials. Therefore, it makes students do not exactly focus on linguistics acquisition. In addition, they are suggested to learn other courses to fulfill the curriculum implementation at the campus. As a result, the curriculum of English development needs to have a review for the sake of students' English mastery and expectations.

\section{Conclusion}

To conclude, this study explores the English-speaking problems viewed from the pre-service English teachers' perspectives. Based on the interview, it was found that the problems mostly encountered by them in speaking English include the lack of grammar mastery, the lack of vocabulary mastery, the lack of correct pronunciation, and the lack of confidence. Therefore, it is highly suggested that future researchers undertake studies in other fields from numerous and wider disciplines. By undertaking it, we could mainly get more insights on some general problems in speaking English and the solutions. Finally, this study may give contributions to English-speaking curriculum development, particularly for students in higher educations.

\section{References}

Basith, A., Musyafak, N., Ichwanto, M. A., \& Syahputra, A. (2019). Chinese learning anxiety on foreign students. European Journal of Educational Research, 8(4), 1193-1200. https://doi.org/10.12973/eu-jer.8.4.1193

Hamzaoğlu, H., \& Koçoğlu, Z. (2016). The application of podcasting as an instructional tool to improve Turkish EFL learners' speaking anxiety. Educational Media International, 53(4), 313-326. https://doi.org/10.1080/09523987.2016.1254889

Pontillas, M. s. (2020). Reducing the Public Speaking Anxiety of ESL College Students Through Popsispeak. 3L: The Southeast Asian Journal of English Language Studies, 26(1), 91-105. 
Scarpino, S. E. et al. (2019). Effects of home language, oral language skills, and cross-linguistic phonological abilities on whole-word proximity in spanish-english-speaking children. American Journal of SpeechLanguage Pathology, 28(1), 174-187.

https://doi.org/10.1044/2018_AJSLP-18-0050

Student 1. (2021). Interview, 10 April 2021.

Student 10. (2021). Interview, 10 April 2021.

Student 2. (2021). Interview, 10 April 2021.

Student 3. (2021). Interview, 10 April 2021.

Student 4. (2021). Interview, 10 April 2021.

Student 5. (2021). Interview, 10 April 2021.

Student 6. (2021). Interview, 10 April 2021.

Student 7. (2021). Interview, 10 April 2021.

Student 8. (2021). Interview, 10 April 2021.

Student 9. (2021). Interview, 10 April 2021.

Talley, P. C., \& Hui-ling, T. (2014). Implicit and Explicit Teaching of English Speaking in the EFL Classroom. International Journal of Humanities and Social Science, 4(6), 38-46.

Thomson, H. (2017). Building Speaking Fluency with Multiword Expressions. TESL Canada Journal, 34(3), 26-53. https://doi.org/10.18806/tesl.v34i3.1272

Troike, M. S. (2006). Introducing Second Language Acquisition. Cambridge University Press. https://doi.org/10.1017/s0272263107070301

Tsai, C. (2018). The Effects of Communication Strategy Training on EFL Speaking Anxiety and Speaking Strategy among the Community College Adult Learners in Taiwan. International Forum of Teaching and Studies, 14(2), 3-19.

Ulla, M. B. (2018). English language teaching in Thailand: Filipino teachers' experiences and perspectives. Issues in Educational Research, 28(4), 1080-1094.

Wahyuningsih, S. (2018). The Use of Video to Enhance Speaking Proficiency in Broadcasting: Perceptions of Undergraduate Students. International Conference on Linguistics.

Wahyuningsih, S., \& Dewi, S. (2019). Promoting Speaking Proficiency in Broadcasting Through YouTube Project: Perceptions of Undergraduate Students. Proceedings of Third English Language and 
Literature International Conference, 1-7.

https://doi.org/10.4108/eai.27-4-2019.2285332

Wood, C., Fitton, L., Petscher, Y., Rodriguez, E., Sunderman, G., \& Lim, T. (2018). The effect of e-book vocabulary instruction on spanishenglish speaking children. Journal of Speech, Language, and Hearing Research, 61(8), 1945-1969. https://doi.org/10.1044/2018_JSLHR-L17-0368 